\title{
Developing sustainability: sustainability policy and gentrification on Toronto's waterfront
}

\author{
Susannah Bunce* \\ Department of Social Sciences, University of Toronto Scarborough, 1265 Military Trail, Toronto, \\ ON, Canada MIC $1 A 4$
}

\begin{abstract}
A "three pillar" concept of sustainability guides the current publicly funded planning and redevelopment process on Toronto's waterfront. While this concept serves as a guiding framework, sustainability is largely defined in planning and redevelopment policy and practice by multi-level public sector urban intensification policy and a reliance on the private sector-led implementation of new sustainable communities. This study connects perspectives on "policy-led gentrification" and "third-wave gentrification" with an exploration of public plans and development strategies for the new West Don Lands waterfront neighbourhood. It traces how sustainability objectives are integrated into a gentrification process driven by public sector planning and development policies and private sector development interests. Components of the integration of sustainability into gentrification practices are the sale of publicly owned waterfront lands to private developers and public sector financial and educational incentives for private real estate development that meets Leadership in Energy and Environmental Design sustainability targets.
\end{abstract}

Keywords: urban sustainability; urban planning; urban intensification; gentrification; sustainability policy; urban waterfronts

\section{Introduction}

Toronto's central waterfront has served as the terrain for various public sector planning and redevelopment strategies over the course of the twentieth century. From the Toronto Harbour Commission's 1912 plan for industrial development and land creation to midcentury modernist plans for residences and recreational spaces, the scope of public sector planning has been constituted by broader political-economic transformations and shifts in governmental responses to civil society and private sector interests. The most recent phase of development marks a new period of change on Toronto's central waterfront ${ }^{1}$ through the integration of a sustainability agenda into the planning, design, and redevelopment processes.

Since 2004, a broad concept of sustainability has been defined through policies and strategies for residential and commercial redevelopment put forward by the Toronto Waterfront Revitalization Corporation (TWRC), a publicly legislated and funded urban development corporation. As articulated in the Sustainability framework, the TWRC's official sustainability policy document, the development corporation defines sustainability as

*Email: scbunce@utsc.utoronto.ca 
the interrelationship and balance of the three pillars of economic development, social growth, and environmental protection (TWRC 2005a, p. 1). Political support for sustainability by the TWRC and different scales of the public and private sector interests have encouraged a connection of these broad sustainability principles with current and future urbanisation practices on the central waterfront. This focus has, in turn, created a localised understanding of waterfront sustainability defined by the policies and implementation strategies that are specific to TWRC's planning and development agenda. An emphasis on implementing a broad definition of sustainability into specific and tangible implementation strategies of planning and real estate development on the waterfront has turned policy and planning attention towards how the concept of "sustainability" will be adapted in practice. The purpose of implementing a broad conceptual definition of sustainability into planning policies and real estate development strategies is described by the TWRC in its statement that "sustainability is the new imperative for cities in the 21 st century and the Toronto waterfront will be distinguished by its leadership on sustainability. The question is not if we will do it but how we will do it" (TWRC 2005a, p. 1).

The integration of sustainability objectives into urban revitalization and planning policies is particularly evident in European and North American cities where the language of regional growth management and urban intensification is now a common vernacular in urban policy and land use planning (Jenks et al. 1996, Thomas and Cousins 1996, Burchell et al. 1998, 2002, Williams et al. 1999, 2000, Beatley 2000, 2007, Bourne 2001, Calthorpe and Fulton 2001, Neuman 2005). As Layard (2001, p. 1) suggests, "(l)and use planning and sustainable development seem to be ever more inextricably intertwined. References to the ideas, principles and policies underpinning sustainability are everywhere - from planning policy guidance to good practice guides to inclusions in development plans". The incorporation of sustainability principles into urban policy, planning, and development processes, however, is also situated within broader political-economic contexts of contemporary neo-liberal urban economic restructuring and governance changes that facilitate private sector involvement and investment in urban planning and urban land redevelopment (Brownill 1990, Healey 1990, 1992, 1995, Fainstein and Fainstein 1986, Harvey 1996, Allmendinger 1997, Oatley 1998, Kipfer and Keil 2002, Peck and Tickell 2002, Adair et al. 2003, Cameron 2003, Steinacker 2003). This context raises the problem of how sustainability concepts and objectives are absorbed into urban policy, planning, and development processes given a shift towards a greater reliance on the role of private sector actors in the implementation of public policies and plans for sustainability.

As sustainability principles are embedded in the language and practices of new urban policies, questions of why and how the integration of sustainability principles in public sector urban redevelopment policies occur, and analyses of private sector implementation of sustainability policies become increasingly relevant for the examination of contemporary urbanisation processes and the study of local forms of sustainability, particularly social sustainability. Scholarly attention to the role of sustainability in public sector urban redevelopment policy and the participation of private sector developers in the implementation of such policy recently explores how urban sustainability policies are allied with market-oriented land development practices (Tallon and Bromley 2004, Raco 2004,2005 , Bromley et al. 2005, Boddy 2007). Further, critical discussions on the connections between urban sustainability policies and gentrification processes (Lees 2003, Davidson and Lees 2005, Davidson 2006) examine the problem of how definitions of sustainability are integrated with profit maximisation strategies for urban land development, associated with urban middle-class consumer demands, and part of the production of both socially exclusive and exclusionary city spaces. Attention to these problems in the context 
of the planning and redevelopment process on Toronto's waterfront allows for an understanding of how sustainability, urban planning, and land redevelopment coalesce in the context of Toronto's urbanisation process and contributes a Canadian example to a growing literature on the associations between urban sustainability policies and gentrification practices.

The methods by which the TWRC's definition of sustainability is connected with the TWRC's planning and real estate development strategies are of central concern in this article. The paper is based upon interview and policy analysis research conducted between 2004 and 2007 that examined the formulation and implementation of public sector sustainability policy for the redevelopment of Toronto's central waterfront. The research focused on a study of the West Don Lands site, an 85 acre deindustrialised area of the central waterfront that is located east of Toronto's financial district, west of the Don River, and north of the Lakeshore Boulevard roadway. The study findings demonstrate that the TWRC's broad definition of sustainability, as translated into specific planning and development strategies for the creation of sustainable communities on Toronto's central waterfront, rests upon the vision and future implementation of high-density, mixed-use residential and commercial districts. The TWRC's particular definition of sustainability allies itself with policies and planning practices of urban intensification. As such, the plans and designs for high-density communities, formulated by different levels of government and also by the TWRC in conjunction with contracted private sector planning and design firms, take a central role in the implementation of the TWRC's vision of waterfront sustainability.

In addition to the associations between the TWRC's definition of sustainability and sustainable urban revitalisation plans, this paper also shows that the TWRC's plans and designs for the development of sustainable residential and commercial communities in the central waterfront are wholly dependent upon private sector development companies for implementation. The majority of the land in the West Don Lands area that is currently owned by the Ontario Realty Corporation - a provincial government realty corporation will be sold at or above market rates to large and well-financed private sector developers. The developers will be chosen through a formal selection process by the TWRC. In order to achieve the TWRC's policy targets for sustainability, adherence to sustainability requirements such as Leadership in Energy and Environmental Design (LEED) ${ }^{2}$ ratings are a condition of public land sale to private sector developers. The coordination of TWRC efforts with private real estate development interests points not only to an alliance between government agencies and the private sector in the redevelopment of urban areas, but to an association between public and private sectors in the implementation of sustainability objectives in new real estate. The TWRC's planning and development strategies offer an example of the integration of sustainability objectives into public sector-formulated policies and development strategies for a new waterfront community in alliance with the development efforts of private sector developers. The purpose of implementing a broad concept of sustainability in private sector-provided and market-oriented residential and commercial development is connected to both current scholarly interpretations and everyday practices of urban gentrification.

The institutional policies for developing a sustainable community in the West Don Lands through the sale of public lands to private developers provide an illustration of "policy-led gentrification" (Lees 2003, Slater et al. 2004, Slater 2006, Lees et al. 2008). The TWRC's formulated planning and development strategies for the eventual private sector provision of housing and commercial space in the new West Don Lands neighbourhood also demonstrate features of "third-wave gentrification" (Hackworth and Smith 2001, 
Hackworth 2002). In what is considered to be the most recent phase of urban gentrification, a key tenet of third-wave gentrification is the increasingly multifarious association between public sector and private sector interests in urban development. Two central aspects of an evolving complexity of public-private arrangements are: (i) a growth in large real estate developers with access to intricate financing networks and (ii) evidence of financial and educational incentives from the government to facilitate private sector investment in urban land development (Hackworth and Smith 2001). The policies and specific strategies for a new sustainable waterfront community on Toronto's waterfront are indicative of policy-led gentrification and are closely allied with key features of third-wave urban gentrification.

\section{The Toronto Waterfront Revitalization Corporation and waterfront sustainability policy}

The Toronto Waterfront Revitalization Task Force ("Task Force") was appointed in 1999 by the federal, provincial, and municipal levels of government in order to develop a concerted public effort at revitalising the central waterfront. The Task Force evolved into an official public urban development corporation, the TWRC, in January 2002. With a dedication of $\$ 1.5$ billion of government funds ${ }^{3}$ originally earmarked for Olympic Games development and maintained for revitalisation efforts, the TWRC was formed to plan what is expected by the development corporation to be, upon completion, the largest publicly financed urban development project in Canadian history (TWRC 2003). An amicable connection between the TWRC and private sector actors has been evident since the development corporation's formation. The first publicly announced redevelopment strategy of the TWRC encouraged private sector investment activities in order to continue public financing of central waterfront redevelopment over the course of 30 years along with an expectation that the redevelopment project will create an annual return on public investment of approximately $14 \%{ }^{4}$ A cited strategy for garnering the return on public sector investment is the sale of public land to private developers (TWRC 2002, p. 18). Although the sale of public lands to the private sector is a familiar strategy of development in Toronto's central waterfront history, it differs in the current phase of development. This situation is due to the TWRC's integration of public sector-driven sustainability requirements into the land sale process and a reliance on the private sector provision of sustainability requirements in new residential and commercial development.

The Sustainability framework ("framework") informs the development of all TWRC procedures and policies including the plans and development strategies for the West Don Lands (Interview 2). Currently, the sustainability policy not only informs all new policies and plans, but also their contracts for hiring private sector consultants and staff persons as well as request for proposals from private consultancy firms and developers. The framework articulates the planning and development of new waterfront communities as the core implementation strategy of the TWRC's broader, "three pillar" sustainability vision. This broad understanding is corrected to an emphasis on measuring sustainability outcomes in the context of land use planning and development. The framework states that, "(s)ustainable communities need to measure performance in terms of outcomes. . .mixed use patterns are of little benefit, for example, if people still travel outside of the area to schools, jobs, and recreational facilities. . . ( $\mathrm{t}$ )he same is also true for development of brownfields. . (s)ustainability outcomes are multi-dimensional and focused on long-term viability" (TWRC $2005 a$, p. 7). Such focus on a transformational notion of sustainability rather than a static understanding points to a longevity in the development of sustainable communities, but 
also supports the on-going technical involvement of the TWRC in the evaluation of sustainability targets. It also shows a connection between the implementation of sustainability in terms of high-density planned communities on the waterfront and an applied and technical notion of sustainability based on this definition. While the framework does not specify plans for land use changes, it provides a list of sustainability targets, primarily articulated through LEED specifications, that have been transcribed into the land use plan and design specifications for the new West Don Lands neighbourhood. The targets are placed in the TWRC's (2006a) green design document, the Performance specifications for green building initiative for West Don Lands ("Green design guidelines"), which serves as the official institutional guideline for integrating sustainability into land use planning and property development. Both the framework and the Green design guidelines operate concurrently with the TWRC's land use planning and urban design policies for new development in the West Don Lands, the West Don Lands precinct plan (TWRC 2005b) and the West Don Lands block plan and design guidelines (TWRC 2006b).

\section{Policy-led gentrification and sustainable urban revitalisation}

Recent discussions have pointed to the ways in which the built form intensification objectives of urban revitalisation policies augment gentrification practices through their reliance on private sector involvement. They have also addressed the ways in which urban revitalisation policies serve as discursive guises for gentrification practices, through the use of seemingly progressive policy concepts such as urban regeneration, residential mixing, and urban sustainability. The literature on policy-led gentrification is important for understanding how sustainability and intensification policies have become cornerstones of public urban policy agendas, and further, how the focus of these agendas emphasises a middle-to-upper income rehabitation of existing city spaces. Increasingly, gentrification research is pointing to the associations between the sustainable urban planning policy agenda of urban intensification and practices of gentrification in cities.

Adair et al. (2003) observe a strong trans-Atlantic influence in urban revitalisation policies and implementation practices. Both the United States and Britain sparked the formulation of national urban policies for urban growth management. ${ }^{5}$ The United States has moulded a national smart growth policy agenda since 1998 (Steinacker 2003), but, due to differences in federal funding, responsibility for the formulation and implementation of smart growth policy is taken at the municipal level in the United States. In Britain, however, the development of an urban growth management and urban revitalisation policy agenda has been centrally formulated and managed by the national government. The undertaking of a national urban revitalisation policy agenda has greatly directed urban planning and development processes in Britain, and this impact has, in turn, shaped the policy discourses and implementation practices of Canadian urban planners. ${ }^{6}$ The centrality of the British national urban revitalisation (regeneration) agenda to contemporary urban planning and development has caused the bulk of research on policy-led gentrification to be conducted by scholars using British empirical cases. Further, some of this research has incorporated analyses of the Labour government's formulation of urban sustainability policy into analyses of policy-led gentrification. This work has much to offer for analyses of sustainability and revitalisation in Canadian urban contexts.

Since the election of the British Labour government in 1997, comprehensive policies for urban planning and development have emphasised what Bromley et al. (2005, p. 2408) call the, "intertwined goals of regeneration and sustainability" through the process of urban intensification. Lees (2003, p. 61) explains that both intensification and sustainability are the central 
concepts of Labour's urban revitalisation (regeneration) campaign. She expands on this point by noting that, "urban policy statements have invoked a discourse of 'urban renaissance' that interweaves calls for urban sustainability with a prescription of concepts and ways of living [a 'back to the city' lifestyle] that are closely tied to gentrification practices" $(2003$, p. 61). Lees makes an association between sustainability, as defined through the lens of urban intensification, a prescribed reduction of suburban, automobile-dependent lifestyles, and a middleclass-driven "back to the city" policy agenda that supports a closer arrangement between work and home in cities. Lees (2003, p. 75) suggests that the concept of sustainability is defined in terms of an "environmentally sustainable urban renaissance", where, "the foundation for urban renaissance and sustainability is the densification of urban form".

Other gentrification researchers have associated cornerstone policies of the British government's urban revitalisation agenda, such as Towards an urban renaissance (DETR 1999) and the Urban white paper, our towns and cities: the future - delivering an urban renaissance (DETR 2000), with gentrification. Smith (2002) makes the association between the "back to the city" thrust of these policies and urban gentrification via development on brown-field sites and other forms of urban intensification. In critiquing these policies, Smith addresses the environmental aspect of urban regeneration policies and connects their environmental objectives with gentrification practices through his assertion that, "enveloped as regeneration, gentrification is recast as a positive and necessary environmental strategy" (Smith 2002, p. 445).

Lees $(2000,2003)$ and Smith (2002) critically observe how the discourse of the Labour government's urban revitalisation agenda is not labelled as a gentrification strategy by the government, but rather serves only as a scholarly category for gentrification researchers in order to conceptualise the intent and impacts of urban revitalisation policies. In the case of Labour's urban revitalisation policies, gentrification is considered by critical gentrification scholars to be the genuine policy strategy and material outcome of the policies, as a result of Labour's emphasis on urban intensification through property-led regeneration (Adair et al. 2003). In this context, some gentrification researchers have turned their attention to how the discourse of urban revitalisation obfuscates gentrification practices through the use of positive and encouraging terms such as "sustainability" and "regeneration".

The use of ostensibly positive and "holistic" terms such as sustainability and regeneration dampens critiques of, and active resistance to, the effects of policy-led gentrification, such as policies that support middle-to-upper income-oriented property development instead of affordable housing. It thus becomes increasingly challenging for academics, practitioners, politicians, and activists to argue against such seemingly positive and encouraging policy terms and concepts. Sustainability, for example, has become a celebrated policy concept for environmental activists despite being concurrently embedded in the policy language of private sector-driven and property-led urban revitalisation. This situation increasingly poses an interesting and challenging balancing act between the demands of environmental activists, for such ecological benefits as less automobiledependent cities and the reduction of urban sprawl, and the concerns of social justice advocates about the impacts of market-oriented property development on income disparity in cities.

In a specific analysis of the concept of urban regeneration in urban policy, Furbey (1999) remarks that regeneration is, "a distinctive idea. It can be distinguished from pragmatic 'redevelopment' in that it evokes a sense that a situation is being enlivened or rejuvenated". This distinction in terminology is certainly echoed in the context of Toronto's waterfront redevelopment process, where the TWRC marks a difference between the concepts of redevelopment and revitalisation. The TWRC states that, "the difference between 
redevelopment and revitalization is that redevelopment will occur on its own, real estate development will occur, economic pressures, time, it will happen. You don't need the corporation (TWRC) to do that. You need the corporation to achieve a social agenda, and the social agenda is one of sustainable revitalisation - which is how do you create a quality of place and a quality of life" (Interview 5). A difference is made in the TWRC context between a social agenda being forwarded through the conceptual formulation and implementation of public policy and the ostensibly more mundane practices of real estate development.

The demarcation between furthering a social agenda through policy and "on the ground" real estate development practices also creates a separation between the role of policy concepts and the role of practical implementation, and by doing so hides the responsibilities of policy concepts away from what actually occurs when policy is implemented. Smith (2002, p. 441), for example, in discussing the British government's discourse of urban regeneration, states that, "[the] class nature of the process of gentrification is assiduously hidden in the verbiage of the British Labour government". Here, policy-led gentrification is not literally translated from policy text into implementation but found implicitly in the assumptions of policy and implemented in practice through the varied and tangled arrangements with private sector interests.

Multi-scalar policies and planning strategies for urban intensification as a growth management practice have driven the formulation of the TWRC's plans and design strategies for the West Don Lands. The current emphasis of the Province of Ontario on urban and regional growth management through intensification practices, dictated through the Places to grow policy and legislation (Province of Ontario 2005, 2006), directs municipal strategies for intensification and advocates for a shift in development practices towards a high-density, mixed-land use provision of residential and commercial spaces. The public discourse of smart growth planning that has been present in Ontario since the early 2000s (Bourne 2001) has influenced the formulation of Toronto-based planning policies for urban intensification as well as the Province of Ontario's mandate for future municipal level intensification. Toronto's master plan (City of Toronto 2002b) sets out a vision and strategies for encouraging intensification as a sustainable urban planning exercise over the next 30 years (Bunce 2004), and also guides the formulation of corresponding municipal plans for specific geographic areas, such as the central waterfront, with similar intensification emphases (City of Toronto 2002a). Toronto's master plan and central waterfront plan directly connect a vision and strategies for intensification with a conceptual notion of sustainable urban revitalisation, thus intensification, in planning discourse, is understood as the conduit for achieving an "end product" of sustainable urban revitalisation. The concepts and implementation strategies of these policies have influenced the TWRC's definition of sustainability, particularly through close cross-over work of urban planning consultants who were involved in the formulation of urban intensification policies at the provincial and municipal levels of government and who were also involved in the formulation of the TWRC's planning and design strategies. ${ }^{7}$

Policies and legislation for urban intensification created at different policy scales in the province of Ontario omit a key issue of intensification practice pertaining to which actors eventually implement urban intensification policy. In keeping with the arguments of policyled gentrification and in light of market-driven private property agendas in cities such as Toronto, the provision of higher-density built form is increasingly delivered by private development companies. The evolving alliances between public sector policy directives and private sector implementation of built form are a key component in the delivery of urban intensification. For the TWRC, increasing density, both in population and in built 
form, ${ }^{8}$ is a way to illustrate the financial benefits of intensified land use for private developers. The TWRC's strategy for urban intensification in the West Don Lands centres on a plan of 24 residential and commercial development blocks in four sections of the neighbourhood. While specific densities are not inscribed in the West Don Lands precinct plan or the companion urban design guidelines, the TWRC provides approximations of the density and form of the development blocks in order to offer private developers a means of understanding development yields from each block. The TWRC's estimations forecast a dense use of built form space and level of residential population, with small residential units of $90 \mathrm{sq} \mathrm{ft}$. on average (TWRC 2006b). These approximations allow the TWRC to provide a rubric for built form and population density to developers in order to gauge the prospective quantity of residential and commercial units. By the TWRC doing this work in advance of development, developers are provided with estimations needed to evaluate the type of necessary development financing, the potential cost of housing, and the variety of housing that will be provided.

The TWRC also makes a connection between higher densities of population activity and building space as a sustainable urban practice and the financial benefits of denser development for private developers. The corporation suggests that increased population density in urban areas stimulates residential development, the provision of commercial services, as well as the provision of public services, as it allows for less costly and more efficient public infrastructure (Interview 5). The financial benefits of higher densities within a single area for private developers are a denser consumer market as well as increases on building density and height for the provision of market-oriented residential and commercial units situated in multi-storey buildings. Urban intensification in the West Don Lands creates a quid pro quo situation for the TWRC and private developers because it addresses the public sector goals of creating sustainable urban form through intensification practices and private sector development interest in maximising profits through the provision of higher-density residential and commercial buildings. The formulation of urban intensification as a sustainable urban revitalisation strategy, to be implemented by private developers, highlights policy-led gentrification in the West Don Lands.

\section{Third-wave gentrification and the development of sustainability on Toronto's waterfront}

Contemporary gentrification can be defined as a state-facilitated process via the concepts and implementation of public urban intensification policies meant to promote a new social and environmental form of urban living. Such policies, however, are also largely predicated on the need to alleviate supply-side constraints to private sector involvement in land development (Hackworth and Smith 2001, Smith 2002, Adair et al. 2003, Steinacker 2003, Davidson and Lees 2005). The concept of third-wave gentrification put forward by Hackworth and Smith (2001) provides a framework for addressing gentrification as a process instigated by alliances between the government and the private sector, encouraged by the tendency of governments to ameliorate conditions for private sector investment in urban land development. This alliance occurs in tandem with the globalisation of urban real estate interests.

While public policy-led gentrification is certainly an aspect of third-wave gentrification, at the core of this new gentrification phase are the increasingly complex associations being formed between governments and the private sector in urban land development practices. In Britain and North America, these alliances are notably evident in government support for more flexible planning and development approaches and assistance programmes for 
private sector developers aimed at easing the perceived risks associated with speculative development (Adair et al. 2003). Visions for sustainable urban revitalisation add a new layer of complexity to the associations between government and private developers in planning, land development, and the provision of housing, which points to the inclusion of sustainability objectives in this new phase of gentrification. With sustainability increasingly becoming a key tenet of urban revitalisation plans, governments have began to ally with private sector land developers over such concerns as the alleviation of the perceived risks associated with developing in accordance with sustainable design specifications. Government programmes and incentives for urban land development and sustainable urban revitalisation are tied together in gentrification processes.

Third-wave gentrification is temporally categorised as "post-recession gentrification" (Lees 2000, Hackworth and Smith 2001, Hackworth 2002, Lambert and Boddy 2002, Rose 2004, Slater 2006), following the global economic recession of the late 1980s and early 1990s. Hackworth and Smith (2001, p. 468) characterise three waves of publicprivate sector-associated gentrification over the past three decades, based on empirical investigations of New York City neighbourhoods. The first gentrification phase was characterised by sporadic government-led interventions to ease private market disinvestments in inner-city neighbourhoods, with concurrent maintenance of public housing and other social service programmes. The second period of gentrification, occurring in the late $1970 \mathrm{~s}$ to the end of the 1980s, marked the beginning of a concerted government effort to encourage private sector investment in urban neighbourhood development. In the United States, for instance, federal loans and grants programmes for private sector developers were provided through the Urban Development Action Grants programme, which inspired the national Urban Development Grant programme in Britain in the 1980s (Adair et al. 2003). This effort was was also witnessed in the intensive deregulation of planning mechanisms and government targeting of specific urban land areas for redevelopment, such as the Thatcher government's "simplified planning zones" in Britain (Allmendinger 2002).

Hackworth and Smith (2001) identify two characteristics of the third phase of gentrification, ${ }^{9}$ that provide a point of departure for discussing the role of sustainability in gentrification. First, is their suggestion that the current period of gentrification shows an increasing globalisation of the real estate sector, which has led to larger development corporations being involved in neighbourhood level gentrification processes. Second, is their argument that different levels of government are increasingly involved in the gentrification process by comparison with the first and second gentrification phases. Gentrification has now become a, "crucial urban strategy for city governments in consort with private capital in cities around the world" (Smith 2002, p. 440). This strategy, according to Smith, has different manifestations in varied locations depending on the routes of global investment capital, structures of government, state policies, and labour configurations (Smith 2002 , 443). Here, governments do not serve as mitigating bodies to counter private sector disinvestments as per the first phase of gentrification, as noted by Hackworth and Smith, but proactively court globalised investment capital for land development practices while concurrently planning gentrification strategies through policy formulation in consultation with private sector actors.

\section{Large developers and financing for sustainable urban revitalisation in the West Don Lands}

The first aspect of third-wave gentrification is evident in the planning strategies created for the development of the West Don Lands, where the TWRC is working to attract large and 
well-known real estate developers to construct market rate housing in accordance with the TWRC's sustainability specifications. Rather than having individual development companies construct on a per site basis, the TWRC is managing the selection of several key private development corporations, based on the merits of their development proposals, to purchase and develop large parcels of land in specific areas of the West Don Lands. This strategy is due to the financing arrangements that private developers will require in order to develop at the scale that the TWRC is requesting and because of the financial premiums that developers will face by building in accordance with the TWRC's LEED Gold specifications.

The financing concerns of private development corporations are the primary reason why publicly owned land in these waterfront areas will now be sold to private sector developers rather than leased from the government real estate corporation. This is due to the reticence of private developers to build housing on leased land (Interviews 3, 5, 7), which the TWRC suggests is a result of consumer demand for freehold purchases rather than leasehold arrangements. The reticence on the part of private developers is also because lending institutions require a larger down payment on mortgages for residences built on leased land; a financing situation that the TWRC notes will inevitably dissuade home purchasers and reduce profit returns for financiers, development companies, and also home purchasers once they resell (Interview 5). As the TWRC mentions, private development corporations will receive better financing arrangements if there is more certainty that potential homeowners will be attracted to purchasing homes rather than discouraged by an inability to secure beneficial mortgaging arrangements (Interview 3). The larger scale of land purchase and development that the TWRC is requesting from private development companies in order to construct new-build development also necessitates larger financing packages. For potential private sector developers in the TWRC's planning and development process, the selection of several key private development corporations to develop parcels of land also provides certainty to lending individuals and institutions. As the planning and development process is being tightly managed by the TWRC, the development corporation's arrangement of correct zoning and other planning requirements before land purchases take place, and the orchestration of a "non-piecemeal" approach to land purchases, provide additional financial certainty for developers and their investors.

Larger developers are also able to both attract the necessary financing capital and absorb the upfront premium costs of developing according to LEED residential and commercial sustainability standards (Interview 7). As higher development premiums exist for constructing according to LEED specifications, these add to the initial costs for private developers. In Toronto, large real estate development corporations such as Minto and Tridel are leading the shift towards the provision of sustainable design in market-oriented residential and commercial buildings (Interview 5). In addition to their increased dexterity in arranging financing packages and absorbing possible profit losses, large development corporations have the capital to publicise and market the concept of sustainable urban communities and sustainable building design. An example of this is the intended provision of an "interactive sustainability centre" that the TWRC will house in the West Don Lands for the purpose of educating future home purchasers about sustainability and sustainable buildings. In addition to large development corporations, small and specialised development companies that focus solely on LEED construction are also involved in the TWRC's planning consultation and development process. According to an Ottawa-based firm that specialises in LEED development and has advised the TWRC on LEED specifications, their company's expertise in sustainable design provides a competitive advantage over other development corporations who are just starting to shift towards building according to LEED 
specifications (Correspondence, 9 March 2007). Here, both larger and established development companies with direct access to financing and smaller companies that specialise in sustainable design and are familiar with LEED construction operate fluidly within this aspect of third-wave gentrification.

\section{Public sector incentives and programmes for developing sustainability in the West Don Lands}

The second characteristic of third-wave gentrification that Hackworth and Smith highlight is the increasing government facilitation of gentrification (Hackworth and Smith 2001). In property-led sustainable urban revitalisation, this takes the form of government educational programmes and financial incentives that make it easier and simpler for the private sector to invest in, and develop, sustainable buildings. Different levels of government in Canada are now providing direct incentives to developers to build according to government-endorsed sustainability standards through financial rebates, mortgage offers for home purchasers, and state-funded and facilitated educational programmes.

Private sector real estate developers in Toronto and other Canadian cities are in the early stage of incorporating sustainable design features, particularly LEED specifications, into their development practices (Interviews 4,5 ). While government policies, such as those encouraging urban intensification, provide assurances regarding the positive externalities of sustainable urban development for private developers, developers also require a more tangible definition of sustainability in order to decrease their risks in land purchasing, construction, and housing sales. As a result, sustainable site planning and sustainable building design become increasingly strategic processes for embedding sustainability principles in the private sector-built urban landscape. Sustainable planning and design become ways of "fixing" sustainability in built form as they provide material benchmarks for developers. Green building rating systems such as LEED not only determine different levels of sustainability, but also provide a tangible yardstick for developers by which to calculate and measure their construction costs and evaluate housing. As a result, different levels of government are now creating incentives for sustainable site planning and building design to decrease concerns and potential risks regarding the construction and sale of sustainable buildings and encourage private sector development interest in providing the "public good" of sustainability in urban built form.

Canadian government incentives for sustainable building development ${ }^{10}$ are recommended by the Canadian federal government for implementation at the urban municipal level. One of these methods, tax increment financing (TIF), was used widely in Britain starting in the 1980 s with the intention of attracting private development interests to deindustrialising urban areas and alleviating perceived risks associated with "brownfield" of development. Adair et al. (2003, p. 1073) define TIF as a programme that "allocates future increases in property taxes from a designated area to pay for improvements within that specific area". Property tax revenues sustain continued infrastructure investment in specific development areas and can be used for such activities as sustainable design renovations on the part of home purchasers. TIF programmes provide direct subsidies to development areas and home purchasers, which gives developers a selling point in the marketing of developments and is compatible with the financial aims of intensification for city governments. As Steinacker (2003, p. 493) remarks, urban in-fill development (intensification) "increases the tax base of cities, as more land is brought back on to the tax rolls at higher assessed values". With this, there is evidence to suggest that TIF programmes aimed at encouraging private sector-led sustainable building development 
rely on increased property taxes and property assessments and rest on the premise of strong market-geared residential provision and demand. In other words, gentrification is necessary in order for TIF programmes to generate more direct revenues for new sustainable community areas. In Ontario, TIF programmes will be soon implemented in urban and regional municipalities following a recent amendment to provincial planning legislation. The legislative amendment is designed to further encourage the development of sustainable urban communities in Ontario, including new communities on Toronto's central waterfront.

In addition to fiscal incentives, various levels of government in Canada have focused on the provision of educational assistance for the development of sustainable buildings and communities. The federal government's Ministry of Natural Resources (Natural Resources Canada) has established sustainability workshops on energy-efficient development for private developers, which the TWRC has hosted for developers interested in purchasing land in waterfront locations (Interview 6). Natural Resources Canada's Office of Energy Efficiency has been particularly involved in the provision of educational advice about sustainability to private developers and enticement of private developers to build upon basic energy standards such as Natural Resource Canada's Model National Energy Code for buildings, specifically through the adoption of sustainable design rating systems (Government of Canada 2007). Government efforts to encourage private sector developers to build with sustainable design features were exemplified in a recent governmentsponsored consultative forum for private sector developers on the topic of improving energy reduction practices in Toronto. The forum was scheduled to coincide with a larger national private sector conference on real estate management (Government of Canada 2007).

The LEED Gold rating requirements for the West Don Lands and additional sustainability requirements are outlined in the TWRC's "Green design guidelines". Through the guidelines, the TWRC will "motivate developers to adopt new approaches to building more sustainable buildings; [and] set requirements that, while requiring changes to existing practices, are economically viable in the market" (TWRC 2006a, p. 1). The TWRC is also intending to provide further assurances for developers to build according to LEED Gold specifications. Following consultations with selected private developers in $2005,{ }^{11}$ the TWRC established specific incentives for meeting sustainability targets. The TWRC will provide "first-in incentives" for developers who are the first to develop in the West Don Lands, such as professional expertise on sustainable design and marketing advice regarding the advertisement of LEED buildings in order to highlight the potential "market edge" of sustainable buildings. The TWRC states that, "(g)etting into the precinct early will carry reduced risk since: the TWRC is providing process and technical support to early entrants into the West Don Lands, (and the) TWRC marketing efforts will support the developer's marketing and further enhance the market differentiation sought" (TWRC 2006a, p. 2). The TWRC's proposed "integrated design process" includes the provision of a team of experts in sustainable design, in addition to assistance by the TWRC's Design Review Panel, to work alongside developers in the construction process. These examples illustrate the range of support provided by the TWRC to private developers in order to alleviate concerns about the increased construction premiums associated with the development of sustainable buildings.

As a result of these practices, LEED ratings emerge as comprehensive in scope as they become an integral part of the eventual development of the West Don Lands as a whole, as well as being a tightly controlled aspect of the gentrification process through an on-going discursive relationship between the TWRC and private developers following the sale of public land. The TWRC is requesting a standard of LEED Gold certification for all new 
construction on publicly owned lands that are sold to private development companies. LEED Gold requirements will be embedded in the public land sale agreements, thus allowing the TWRC to play "hard ball" with private developers by making LEED Gold a non-negotiable component of the land sale (Interview 6). Sustainability requirements proposed by the TWRC thus become an entrenched part of the economic motivations for, and legal mechanisms of, private sector land purchase and development on Toronto's central waterfront.

In keeping with Hackworth and Smith's second tenet of third-wave gentrification, there is an increasing alliance between governments and the private sector in orchestrating urban gentrification practices. Through the ability of larger real estate development companies to enable sustainable design and the facilitation of public sector programmes that stimulate private sector interest in market-oriented and "sustainable" real estate, sustainability is integrated with the components of this latest phase of gentrification.

\section{Conclusion}

This paper explores how plans and development strategies for the creation of a new sustainable community on Toronto's central waterfront are connected to the processes of gentrification articulated in the concepts of policy-led gentrification and third-wave gentrification. The TWRC's planning and development strategies emphasise sustainable urban revitalisation through the intensification of urban built form and point to how different scales of sustainable urban revitalisation policy coalesce to encourage the development of new high-density, market-oriented housing and commercial spaces in the West Don Lands area. In keeping with discussions on policy-led gentrification, the TWRC's process encapsulates a "public policy-led, private sector-implemented" approach to the planning and development of a new sustainable community and highlights the complicity of sustainability policy in a gentrification process.

The TWRC's plans and development strategies also connect with two key components of third-wave gentrification practice. First, the increasing role of large and globally financed private development companies rather than individual or family home renovators in current gentrification processes, and second, the growing attention to government incentives to encourage private sector land development in cities. Large private developers and smaller development firms specialised in sustainable design are attracted to the TWRC's development strategies because they are better able to absorb the potential financial risks associated with sustainable construction premiums. Different levels of government and public agencies such as the TWRC are also working to encourage the implementation of sustainability policy and provide increased certainty for private development companies and investors through direct financial and educational incentives. As such, an alliance between the public and private sectors in the coordination of new sustainable building development from the incentive stage prior to land purchase to the completion of construction is evident, particularly through the incorporation of LEED sustainability requirements.

The exploration of the connections between sustainable urban revitalisation and gentrification in the TWRC's planning process and development strategies now raises new questions regarding the social exclusivity of Toronto's waterfront development once construction in the West Don Lands is complete. A gentrified notion of sustainable urban revitalisation will most likely occur at the expense of social equity concerns about affordable housing needs on Toronto's central waterfront and in opposition to a social justiceoriented interpretation of sustainability and planning in the city. 


\section{Acknowledgements}

The author wishes to acknowledge the support of Social Sciences and Humanities Research Council of Canada Grant \#410-2005-2071 in the production of doctoral dissertation research conducted from 2005-2007.

\section{Notes}

1. The central waterfront area is specified as a $10 \mathrm{~km}$ land area that spans west/east in the southern part of Toronto's downtown core and along the shore of Lake Ontario (City of Toronto 2002a).

2. LEED is the most recognised rating system for sustainable design in North America. It is based on a credit system for achieving sustainable design goals in buildings.

3. A dedication of $\$ 500$ million CAD from each of the three levels of government, with terms of reference for allocating this funding based on project time lines. The TWRC is expecting federal funding to conclude in 2008 (Interview 5).

4. This percentage is approximated in terms of the three levels of government receiving \$3 CAD in returns on investment for every $\$ 1 \mathrm{CAD}$ of dedicated public funding (TWRC 2002, p. 18).

5. Due to differences in governance structures, there is a notable difference in urban policy formulation and urban funding, with the national scale in Britain and the United States formulating national-level urban policy. In terms of funding, urban municipalities in Britain receive $75 \%$ of their annual funding from the national government while in the United States urban municipalities receive $13 \%$ of their funding from the federal government (Atkinson 2003, p. 2345). In Canada, urban municipalities are under the legislative, financing, and policy control of provincial governments, and receive little to no direct funding from the national government.

6. Gerald Hodge notes that the British-Canadian connection in urban planning is a result of the similar construct in planning systems and legislation (Hodge 2004). Urban Strategies Ltd., an esteemed Toronto planning and design firm, asserts that the British experience with urban regeneration has greatly influenced current urban planning thought in Canada. A well-known example of this is the link between the work of Olympia and York in London's Canary Wharf development and consultancy on the project by well-known urban planners and architects from Toronto. A Toronto-based planner was responsible for the direction of the Olympia and York's Canary Wharf planning and was later involved in the work of the Toronto Waterfront Task Force (Interview 1 confirmed).

7. An example of this "policy cross-pollination" is Urban Strategies Ltd., a private sector planning and design consultancy in Toronto, was hired by both the City of Toronto and the TWRC to formulate the intensification strategy in the City of Toronto's central waterfront plan and the TWRC's land use plan for the West Don Lands. The firm was also hired by the Province of Ontario to conduct intensification research for the formulation of the Places to grow legislation and policy.

8. Williams et al. $(1999,2000)$ define urban intensification as the densification of both population activity and built form in cities.

9. Lees et al. (2008, p. 180) have recently identified the beginning of a "fourth wave" of gentrification that builds upon the third wave through the "tight integration of local gentrification and global capital markets" and "more state policies to encourage gentrification".

10. The Canadian federal government's National Roundtable on the Environment and Economy recommends that urban municipalities use TIF incentives to encourage private developers to redevelop brown-field areas.

11. The selected developers represented a range of large condominium developers including Shane Baghai Group (a luxury condominium development corporation), Minto Inc., Tridel Inc., The Daniels Corporation, and a specialised sustainable developer, Windmill Developments (TWRC 2006a, G3).

\section{Interviews}

Interview 1: May 19, 2005. Director, Urban Strategies Ltd.

Interview 2: June 9, 2005. Sustainability Co-ordinator, Toronto Waterfront Revitalization Corporation. Interview 3: September 14, 2005. Consultant, N. Barry Lyons Consulting. 
Interview 4: November 23, 2005. Vice President of Planning and Design, Toronto Waterfront Revitalization Corporation.

Interview 5: January 18, 2006. Chief Executive Officer, Toronto Waterfront Revitalization Corporation.

Interview 6: December 15, 2006. Director of Sustainability, Toronto Waterfront Revitalization Corporation.

Interview 7: February 23, 2007. Staff, Development Division, Toronto Waterfront Revitalization Corporation.

\section{References}

Adair, A., Berry, J., and McGreal, S., 2003. Financing property's contribution to regeneration. Urban Studies, 40 (5), 1065-1080.

Allmendinger, P., 1997. Thatcherism and planning: The case of simplified planning zones. Aldershot: Ashgate.

Allmendinger, P., 2002. Planning theory. Houndsmill, Basingstoke: Palgrave Macmillan.

Atkinson, R., 2003. Introduction: misunderstood saviour or vengeful wrecker? The many meanings and problems of gentrification. Urban Studies, 40 (12), 2343-2350.

Beatley, T., 2000. Green urbanism: learning from European cities. Washington, DC: Island Press.

Beatley, T., 2007. Planning for sustainability in European cities. In: R. LeGates and F. Stout, eds. The city reader. 4th ed. London: Routledge, 411-421.

Boddy, M., 2007. Designer neighbourhoods: new-build residential development in non-metropolitan UK cities - the case of Bristol. Environment and Planning A, 39 (1), 86-105.

Bourne, L., 2001. The urban sprawl debate: myths, realities and hidden agendas. Plan Canada, 41 (4), 26-28.

Bromley, R., Tallon, A., and Thomas, C., 2005. City centre regeneration through residential development: contributing to sustainability. Urban Studies, 42 (13), 2407-2429.

Brownill, S., 1990. Developing London's docklands: another great planning disaster? London: Paul Chapman.

Bunce, S., 2004. The emergence of "smart growth" intensification in Toronto: environment and economy in the new official plan. Local Environment, 9 (2), 177-191.

Burchell, R., et al., 1998. The costs of sprawl - revisited. Washington, DC: National Academy Press.

Burchell, R., et al., 2002. The costs of sprawl - 2000. Washington, DC: National Academy Press.

Calthorpe, P. and Fulton, W., 2001. The regional city: planning for the end of sprawl. Washington, DC: Island Press.

Cameron, S., 2003. Gentrification, housing re-differentiation and urban regeneration: "going for growth" in Newcastle upon Tyne. Urban Studies, 40 (12), 2367-2382.

City of Toronto, 2002a. Making waves: central waterfront part II plan. Toronto, ON: City of Toronto.

City of Toronto, 2002b. Toronto official plan. Toronto, ON: City of Toronto.

Davidson, M., 2006. New build gentrification and London's riverside renaissance. Unpublished dissertation $(\mathrm{PhD})$. University of London, London.

Davidson, M. and Lees, L., 2005. New-build gentrification and London's riverside renaissance. Environment and Planning A, 37 (7), 1165-1190.

DETR (Department of the Environment, Transport, and the Regions), 1999. Towards an urban renaissance. London: DETR.

DETR (Department of the Environment, Transport, and the Regions), 2000. Our towns and cities: the future - delivering an urban renaissance. London: DETR.

Fainstein, N.I. and Fainstein, S.S., 1986. Restructuring the city: The political economy of urban redevelopment. New York: Longman.

Furbey, R., 1999. Urban "regeneration": reflections on a metaphor. Critical Social Policy, 19 (4), 419-435.

Government of Canada, 2007. Office of energy efficiency [online]. Natural Resources Canada. Available from: www.oee.nrcan.gc.ca [Accessed 13 June 2007].

Hackworth, J., 2002. Post-recession gentrification in New York City. Urban Affairs Review, 37 (6), $815-843$.

Hackworth, J. and Smith, N., 2001. The changing state of gentrification. Tijdschrift voor Economische en Sociale Geografie, 92 (4), 464-477. 
Harvey, D., 1996. Justice, nature and the geography of difference. London: Blackwell.

Healey, P., 1990. Land and property development in a changing context. Farnham: Gower Press.

Healey, P., 1992. Re-building the city: Property led regeneration. London: E\&FN Spon.

Healey, P., 1995. Managing cities: The new urban context. London: John Willey \& Sons.

Hodge, G., 2004. Planning Canadian communities: an introduction to the principles, practice and participants. 4th ed. Toronto, ON: Nelson Thomson.

Jenks, M., Burton, E., and Williams, K., eds., 1996. The compact city: a sustainable urban form? London: E\&FN Spon Ltd.

Kipfer, S. and Keil, R., 2002. Toronto Inc? Planning the competitive city in the new Toronto. Antipode, 34 (2), 227-264.

Lambert, C. and Boddy, M., 2002. Transforming the city: post-recession gentrification and re-urbanisation [online]. Centre for Neighbourhood Research Paper, CNR Paper 6. Available from: http://www.neighbourhoodcentre.org.uk [Accessed 28 February 2007].

Layard, A., 2001. Introduction: sustainable development - principles and practice. In: A. Layard, S. Davoudi and S. Batty, eds. Planning for a sustainable future. London: Spon Press, 1-6.

Lees, L., 2000. A re-appraisal of gentrification: towards a geography of gentrification. Progress in Human Geography, 24 (3), 389-408.

Lees, L., 2003. Visions of "urban renaissance": the urban task force report and the urban white paper In: R. Imrie and M. Raco, eds. Urban renaissance? New labour, community and urban policy. Bristol, UK: Policy Press, 61-82.

Lees, L., Slater, T., and Wyly, E., 2008. Gentrification. London: Routledge.

Neuman, M., 2005. The compact city fallacy. Journal of Planning Education and Research, 25 (1), 11-26.

Oatley, N., 1998. Economic competition and urban policy. London: Paul Chapman Publishing Ltd.

Peck, J. and Tickell, A., 2002. Neoliberalizing space. Antipode, 34 (3), 380-404.

Province of Ontario, 2005. Places to grow: a proposed growth plan for the greater golden horseshoe. Toronto: Queen's Printer, Province of Ontario.

Province of Ontario, 2006. Places to grow: growth plan for the greater golden horseshoe. Toronto: Queen's Printer, Province of Ontario.

Raco, M., 2004. Urban regeneration in a growing region: the renaissance of England's average town. In: C. Johnstone and M. Whitehead, eds. New horizons in British urban policy: perspectives on new labour's urban renaissance. Aldershot, UK: Ashgate Press, 41-58.

Raco, M., 2005. Sustainable development, rolled-out neo-liberalism, and sustainable communities. Antipode, 37 (2), 324-347.

Rose, D., 2004. Discourses and experiences of social mix in gentrifying neighbourhoods: a Montreal case study. Canadian Journal of Urban Research, 13 (2), 278-316.

Slater, T., 2006. The eviction of critical perspectives from gentrification research. International Journal of Urban and Regional Research, 30 (4), 737-757.

Slater, T., Curran, W., and Lees, L., 2004. Guest editorial: gentrification research: new directions and critical scholarship. Environment and Planning A, 36 (7), 1141-1150.

Smith, N., 2002. New globalism, new urbanism: gentrification as global urban strategy. Antipode, 34 (3), 427-450.

Steinacker, A., 2003. In-fill development and affordable housing: patterns from 1996-2000. Urban Affairs Review, 38 (4), 492-509.

Tallon, A. and Bromley, R., 2004. Exploring the attractions of city-centre living: evidence and policy implications in British cities. Geoforum, 35 (6), 771-787.

Thomas, L. and Cousins, W., 1996. The compact city: successful, desirable and achievable? In: M. Jenks, E. Burton and K. Williams, eds. The compact city: A sustainable urban form? London: E\&FN Spon, 53-73.

TWRC (Toronto Waterfront Revitalization Corporation), 2002. Our waterfront: gateway to a New Canada - the development plan and business strategy for the revitalization of the Toronto waterfront. Toronto, ON: Toronto Waterfront Revitalization Corporation.

TWRC (Toronto Waterfront Revitalization Corporation), 2003. Building the foundation: annual report 2002-2003. Toronto, ON: Toronto Waterfront Revitalization Corporation.

TWRC (Toronto Waterfront Revitalization Corporation), 2005a. Sustainability framework. Toronto, ON: Toronto Waterfront Revitalization Corporation.

TWRC (Toronto Waterfront Revitalization Corporation), 2005b. West Don Lands precinct plan. Toronto, ON: Toronto Waterfront Revitalization Corporation. 
TWRC (Toronto Waterfront Revitalization Corporation), 2006a. Performance specifications for green building initiative for West Don Lands. Toronto, ON: Toronto Waterfront Revitalization Corporation.

TWRC (Toronto Waterfront Revitalization Corporation), 2006b. West Don Lands block plan and design guidelines. Toronto, ON: Toronto Waterfront Revitalization Corporation.

Williams, K., Jenks, M., and Burton, E., eds., 1999. How much is too much? Urban intensification, social capacity and sustainable development. Open House International, 21 (1), 17-25.

Williams, K., Jenks, M., and Burton, E., eds., 2000. Achieving sustainable urban form. London: E\&FN Spon. 